Full length article

\title{
OUTCOME AND ROOTS OF EARLY MARRIAGES IN GILGIT-BALTISTAN: A QUANTITATIVE DESCRIPTIVE STUDY
}

\author{
Saima Baigl,* and Asmat Ullah² \\ 1. Sindh Madressatul Islam University Karachi, Sindh Pakistan. \\ 2. Aga Khan University Karachi, Sindh Pakistan.
}

\section{ABSTRACT}

The aim of this study was to find out the causes and outcome of the early marriages in the light of victims and gatekeepers observations. However, one-third of under-aged girls in the developing countries are married before the age of 18 years. Although in Northern areas of Pakistan, early marriage is a very common problem in both gender, especially, in GilgitBaltistan and the ratio is higher than any other part of the country. Moreover, in this region, early marriage is prevailed due to traditional customs, religious dominance and supernatural evil. The present study chose two categories, first category for victims which includes respondents of age group from 10 to 40 years old and married before 18 years of age. The second category was chosen for interpretation of the community gatekeepers. We utilized a quantitative survey method to collect data from each district and examined 200 sample. A sample is divided into two groups, the victim's group includes 150 respondents and the group of gatekeepers includes 50 sample size. The tailor-made close-ended questionnaire was designed for the collection of data. Beside this, a Likert scale was also used for Professionals.

There is a need to take some serious steps to eliminate this social disease which promotes the illiteracy, poverty, crime, economic burden, terrorism, domestic violence and rapid increase in population which is surmounting challenges in the pathway of regional development. Early marriage has psychological, physical and economic consequences; most girls remain unable to complete their primary and secondary education and also have the negative impact on their health.

KEYWORDS: Early Marriage, Causes, Outcome

*Corresponding author: (Email: srbaig100@gmail.comL

\section{INTRODUCTION}

Early marriage is one of the main reason for the rapid growth in South Asia and more than seven hundred million women [1] and 46 percent of South Asian girls got married before 18 years of age. Almost, half of the girls married before the age of 15 , one in five girls are married out of them and it is the highest ratio in the world. While in India 43 percent of women were married between the ages of 20 and 24 from 2005 to 2013 [2].

Around $42 \%$ of girls in Pakistan got married before their $18^{\text {th }}$ birthday and $8 \%$ of adolescents married women are already mother between the ages of 15 and 19 [3].

Globally, early marriages is a common practice in the community and they began to be curious in the $20^{\text {th }}$ century. In ancient and medieval societies, it was common for girls to be engaged even before puberty [4]. 
The prevalence of early marriages, 100 million girls will be married before 18 in next decade and 51 million girls' ages between 15 and 19 will be married worldwide [5] Although, 82\%, 75\%, 63\%, 50\% these percentage of girls in Nigeria, Bangladesh, Nepal, Uganda respectively married before 18 years [6] However, $39 \%$ of the girls in Amahara region Ethiopia married before 15 years of age [7]

The experience of adolescence in Amahara region of Ethiopia joint study of the population, UNITED NATION population fund and UNICEF Population Council 66\%, 12\% the proportion of the girls among Nigeria poorest $20 \%$ and richest $20 \%$ respectively, who married before 18 years of age [8]. Girls who are younger than 15 years are five times more likely to die in childbirth than those in their $20 \mathrm{~s}$ [9].

India is the second highest number of early marriages. The highest ratio of early marriages in Bangladesh, there are two out of every three girls are married before age followed by India, Nepal, and Afghanistan. India has the highest number of unregistered children under the age of five years from 2000 to 2012 and the second highest number of early marriages. According to the UN report, the country still needs to improve immunization coverage and stop gender-based sex selection. The largest number of children under the age of five and 71 million birth is not registered in India from 2002 to 2012. Although, 100 million unregistered children were born in India, Afghanistan, Bangladesh, and Maldives [9].

In developing countries, the majority of the sexual female adolescent are married. Although married adolescent is often assumed to be a low risk for HIV infection and a little is known about actual HIV risk [10]. Unfortunately, motherhood ratio is very high $147 / 1000$ because of early marriages in Pakistan [1 1].

Early marriage affects girls and boys negatively and they suffer from various diseases. Moreover, sexual violence in girls affects them by fistula. Six thousand girls infected daily HIV [12], 60\%, 10\%, $1 \%$ in Mozambique with no education, secondary Schooling and Higher Education respectively married before 18 years of ages [13].

Early marriages are one of the reason of sociocultural belief that create health issues. It was said that more than two million south Asian children die before the fifth birthday of prevalence causes [14], and nearly $38 \%$ of children have chronic malnutrition
[15] Cultural and social pressure lead families to allow early marriages of people in Nigeria [16].

In Pakistan, an urban feminist may be offended to learn that an economist from the World Bank determined that women married in Interchange relationship (Watta Satta) marriages faceless marital discord than the rural in Pakistan. Exchange marriages involve simultaneous marriages of brother and sister from one family pair to another family [16]. Though in any society early marriages are harmful to its growth and affect societies like Pakistan where multiple social problems such as; illiteracy, social crimes, poverty, overpopulation, Economic, psychological and environmental issues are already existing.

UNESCO and UNICEF played a great role to eradicate early marriages in MDGs and they totally focus to stop early marriages. In addition to this, they increase the level of education and formulate an agenda to enhance the level of primary education from 2000 to 2015. They started a global agenda "Education for All" but Pakistan remained unable to achieve the MDGs. The purpose of MDGs is to educate the girls and enable them to raise their voice for their basic rights

\subsection{SITUATION BREAKDOWN OF STUDY ZONE}

The ratio of early marriages in rural areas is higher (62\%) than urban areas (59\%), especially in Gilgit-Baltistan the ratio of early marriage in all districts is 57 percent where women got married before reaching 18 years [17] due to their family and social pressure. Although, it is far-flung rural areas are higher than the main cities. There are diverse typical issues like religious dominance, supernatural events, and economic aspects. Interestingly, the literacy rate in Gilgit-Baltistan is above than $85 \%$ [18] and it is higher than other parts of the county but unfortunately, inhabitants of the region are tightly bound to their traditional and tribal values. Therefore, it is the key factor to drive them for early marriages.

The provincial government was intending to pass anti-child early marriage bill but they faced so many challenges to get it passed in the assembly. One of the strong hurdles was the religious factor which pressurized government and prevented to not pass the bill. In this respect, the early marriages bill could not implement [19]. The early marriage is a common practice that is why the ratio of divorce is high in district Diamer and suicide incidents. 
Moreover, the ratio has been increasing for the last 10 ten years, according to media reports about 300 girls suicide from 2011 to 16 [20]. These girls are directly or indirectly victims of such traditional customs. Most people belong to far-flung areas when reaching puberty and do not marry are supposed to be against the Islamic faith. Another enormous factor is the traditional belief in supernatural evils i.e. shamanism. The shaman boy or girl suffers from this supernatural disease is advised to marry without considering his or her age and this tradition has prevailed mostly in Nager and Rondo. Additionally, government facilities for specific areas of the region in response to forest royalty the people of those particular areas are preferred early marriages than the legal suitable age. The direct benefit of royalties does not go to the newly married couple that is the real beneficiary of the amount whereas the family of the couple gets benefits from the increased royalty on each newborn child [21].

The extended family system is one of the key factors in the local society that leads to early marriages. In extended families, elders decided themselves for their children marriages even without taking any consent from the victims, owing to these typical traditional decisions, children are bound to follow their elders. Another myth or traditional belief is if girls suffer from any disease from her parents keep the vow that the first person come for her will be accepted as her groom for marriage, by doing this act they actually fulfill their vow [22]. Unfortunately, in this type of marriage, most of the victims are survive due to the massive age differences between Spouses i.e. 10 to 15 years commonly observed in the area of Gilgit-Baltistan, which is the part of their rolling stone tribes who live for driving soon marriage of children for domestic assistance. According to MICS survey report, the population growth in the region is very high $4.8 \%$, however, it is difficult to control unregistered marriages and the unregistered birth of children.

This study aims to find out the causes behind the early marriages and their outcome on the victim's life.

\section{MATERIAL \& METHODS}

The present study consists of a quantitative method and survey method used for achievement of the study purposes and the collection of the data from eight districts of Gilgit-Baltistan.

\subsection{Study Design}

The present study was fit into quantitative descriptive research design and respondent divided into two groups' victims and gatekeepers. The first study group based on victims and included set for them which having age group from 10 to 40 years and married before 18 years of age at the time of the study.

The second study group was deliberated for gatekeepers that inclusion criteria set they should be professionals and practitioners.

\subsection{Data Distribution}

In the current study examined 200 cases with 95\% Confidence Interval and 5\% Margin of Error further divided into two groups; the information collected from eight districts of Gilgit-Baltistan. The 150 victims approached through snowball sampling for the first group and for the second group 50 gatekeepers selected while reached to them through the provided list of professionals.

The sample size distribution is mentioned as under the table.

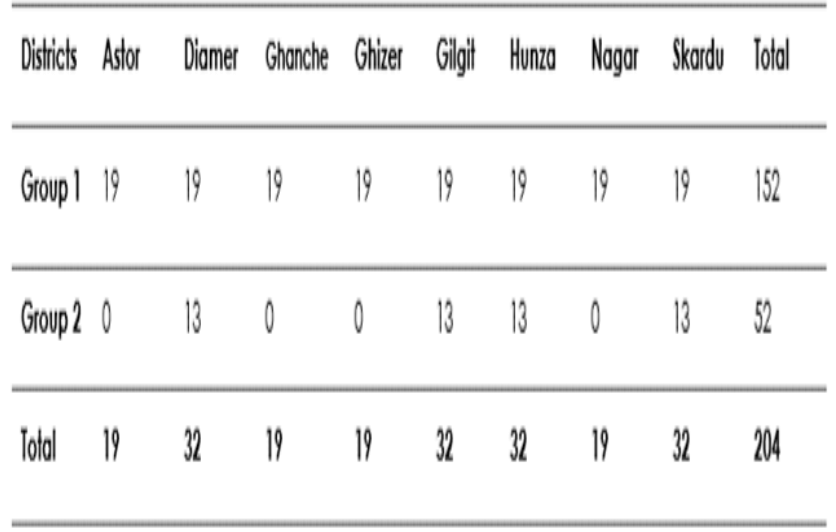

\subsection{Tools:}

Two separate but inter-related, close-ended, and tailor-made questionnaires were designed for the respondents. The first was used for victims that represent the region and the population of strata of both male and female. The second category questionnaire was designed for experts that were structured as a Likert scale towards their perceptions. 


\begin{tabular}{|c|c|c|}
\hline Variable & Description & Measurement \\
\hline Victims & $\begin{array}{l}\text { All those people who were married } \\
\text { before the legal age of marriage. }\end{array}$ & $\begin{array}{l}\text { Marriage age before } 14 \text { years } \\
\text { and } 15 \text { to } 18 \text { years. }\end{array}$ \\
\hline Gatekeepers & $\begin{array}{l}\text { Community Leaders who are } \\
\text { responsible for development i.e. } \\
\text { Professionals, Academicians, media } \\
\text { persons, politicians, religious leaders, } \\
\text { and Practitioners. }\end{array}$ & $\begin{array}{l}\text { The opinion of them count as } \\
\text { strongly agree, agree, neutral, } \\
\text { disagree, strongly disagree. }\end{array}$ \\
\hline Age & Current age & Count as $>=10$ to $<=40$ years \\
\hline Knowledge & Awareness about early marriage & Count as Yes, No. \\
\hline The legal age of Marriage & $\begin{array}{l}\text { As per law } 18 \text { years of age for } \\
\text { mariage. }\end{array}$ & Count as Yes, No. \\
\hline Education & $\begin{array}{l}\text { Carry on education after marriage } \\
\text { by the respondent and their spouse. }\end{array}$ & Count as Yes, No. \\
\hline Health Status & Sustainability of Health. & Count as Yes, No. \\
\hline Domestic Issues & Home-based personal decisions. & Count as Yes, No. \\
\hline Achieved life objectives & $\begin{array}{l}\text { Everyone has the different aim of } \\
\text { life. }\end{array}$ & Count as Yes, No. \\
\hline Population increased & Childbirth frequency. & $\begin{array}{l}\text { Count into five scales strongly } \\
\text { agree, agree, neutral, disagree, } \\
\text { and strongly disagree. }\end{array}$ \\
\hline Maternal Mortality & The death during delivery. & $\begin{array}{l}\text { Count into five scales strongly } \\
\text { agree, agree, neutral, disagree, } \\
\text { and strongly disagree. }\end{array}$ \\
\hline Extended family system & $\begin{array}{l}\text { Whether all members living together } \\
\text { like parents, uncle, aunts, } \\
\text { grandparents and their children. }\end{array}$ & $\begin{array}{l}\text { Count into five scales strongly } \\
\text { agree, agree, neutral, disagree, } \\
\text { and strongly disagree. }\end{array}$ \\
\hline Super Natural forces & $\begin{array}{l}\text { That are beyond the human being } \\
\text { i.e. vampires, werewolves and } \\
\text { ghosts. }\end{array}$ & $\begin{array}{l}\text { Opinion collect from experts. } \\
\text { Count into five scales strongly } \\
\text { agree, agree, neutral, disagree, } \\
\text { and strongly disagree. }\end{array}$ \\
\hline Community development & $\begin{array}{l}\text { To support the enhancement of } \\
\text { education, infrastructure. }\end{array}$ & $\begin{array}{l}\text { Count into five scales strongly } \\
\text { agree, agree, neutral, disagree, } \\
\text { and strongly disagree. }\end{array}$ \\
\hline
\end{tabular}

\subsection{Data Analysis}

We used SPSS version 22 for data entry and data analysis. Data was presented in charts and tables with demonstrations of numbers and percentage.

\section{RESULTS AND DISCUSSION}

\subsection{Study \#01. VICTIM OF EARLY MARRIAGES}

We selected 150 respondents as a victim. They married before 18 years of age. In this paper observed ( $n=32,21.3 \%)$ Male and $(n=118,78.7 \%)$ female as victims of early marriage shows in figure no 1.

\section{Gender of Victims}

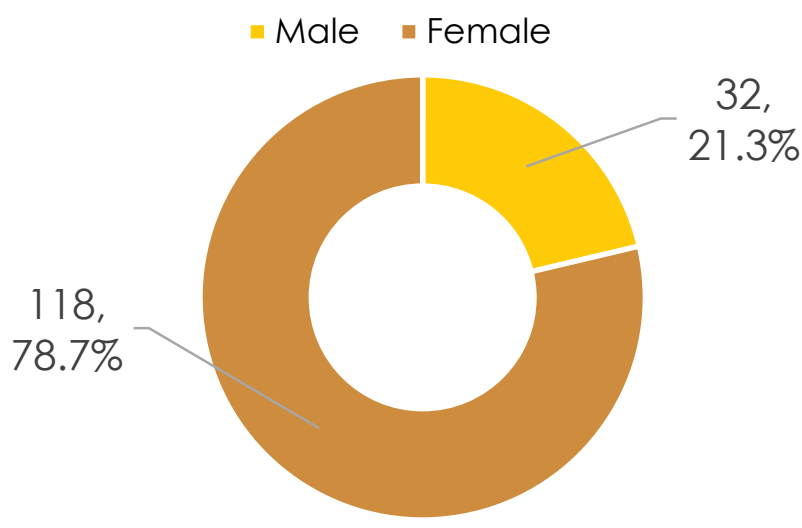

Figure 1: Gender distribution of early marriage victims

Figure 2 shows the victim's age at the time of marriage. We explored ( $n=41,27.3 \%)$ victims were up to 14 years and $(n=109,73.2 \%)$ were 15 to 18 years old at the first time of marriage.

\section{Marriage Age}

\section{Up to 14 Years $\square 15$ to 18 Years}

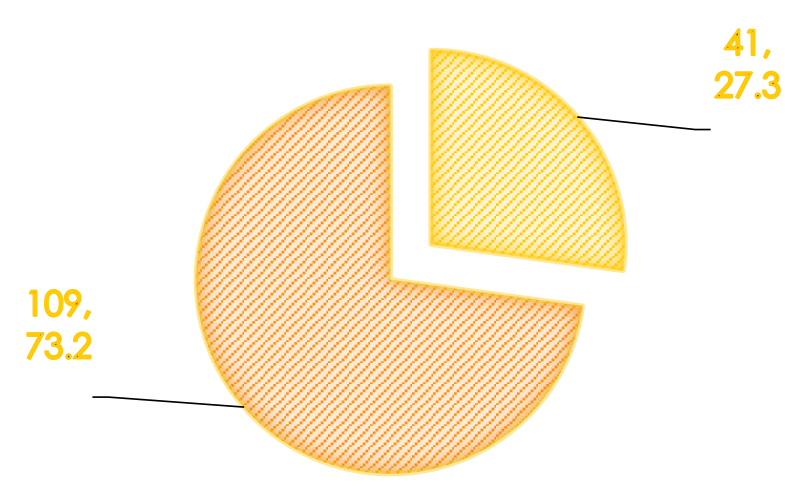

Figure 2: Victims age at the time of marriage

Table 1 shows knowledge of victims about early marriage highest ( $n=96,64.2 \%$ ) respondents did not know about early marriages while, although $(n=54$, $35.7 \%$ ) of victims were good knowledge about it. However, majority victims ( $n=85,56.6 \%)$ were not aware of legal age of marriages though, $(n=65$, $43.3 \%$ ) were good knowledge about legal age of marriages above half of the respondents $(n=93$, $62 \%$ ) were not satisfied to their daily life routine after 
early marriage while $(n=57,38 \%)$ were satisfied. However, $(n=118,78.6 \%)$ of the respondents were not able to continue their education while, $(n=32$, $21.3 \%$ ) respondents were to continue their education after marriage. Although, $(n=109,72.6 \%)$ of the respondents were not sustain health practices after marriage while, $(n=41,27.3 \%)$ of the respondents were sustain their health the highest proportion of the respondents $(n=99,66 \%)$ were not able to handle while, $(n=51,34 \%)$ were able to tackle domestic issues. Although, maximum data shows $(n=123,82 \%)$ of the respondents did not have school going children, however, $(n=27,18 \%)$ of the respondents had school going children, $(n=38$, $25.3 \%$ ) of the respondents achieved life objectives and the highest proportion of $(n=112,74.6 \%)$ of the respondents were not achieved their life objectives for the reason that early marriage.

Table 1: Knowledge and outcome of early marriages

\begin{tabular}{ll}
\hline Indicators & $\mathbf{n = 1 5 0}$ \\
\hline $\begin{array}{l}\text { Knowledge about Child } \\
\text { Marriage }\end{array}$ & $\mathbf{N}=\%$ \\
\hline Yes & $54(35.7)$ \\
\hline No & $96(64.2)$ \\
\hline
\end{tabular}

Knowledge about the Legal age of Marriage in Pakistan

\begin{tabular}{ll}
\hline Yes & $65(43.3)$ \\
\hline No & $85(56.6)$ \\
\hline
\end{tabular}

Satisfied with Married Life

\begin{tabular}{ll}
\hline Yes & $57(38.0)$ \\
\hline No & $93(62.0)$ \\
\hline
\end{tabular}

Currently, continue your Education

\begin{tabular}{ll} 
Yes & $32(21.3)$ \\
\hline No & $118(78.6)$ \\
\hline
\end{tabular}

Currently, sustain your Health

\begin{tabular}{ll}
\hline Yes & $41(27.3)$ \\
\hline No & $109(72.6)$ \\
\hline
\end{tabular}

Able to tackle your domestic issues

\begin{tabular}{ll} 
Yes & $51(34.0)$ \\
\hline No & $99(66.0)$ \\
\hline
\end{tabular}

Your children go to school

\begin{tabular}{lc}
\hline Yes & $27(18.0)$ \\
\hline No & $123(82.0)$ \\
\hline Achieved life objectives & \\
\hline Yes & $38(25.3)$ \\
\hline No & $112(74.6)$ \\
\hline
\end{tabular}

\section{2: STUDY \#02: GATEKEEPER'S \\ INTERPRETATION}

We examined the response of gatekeepers according to the age fixed in the Pakistani constitution ( 18 years and above). In five-point Likert scale responses were as; $44 \%$ gatekeepers were strongly agreed while, $24 \%$ agree, $20 \%$ neutral, $6 \%$ disagree and $6 \%$ strongly disagree. Although, $32 \%$ gatekeepers were strongly agreed to early marriages is the hurdle in community development in Gilgit-Baltistan, 30\% agree, 22\% neutral, $6 \%$ disagree and $10 \%$ strongly disagree. Professionals $44 \%$ strongly agreed to social problems increasing as an outcome of early marriages while, $34 \%$ agree, $12 \%$ neutral, $0 \%$ disagree and $10 \%$ strongly disagree.

- Although we found $10 \%$ results of the professionals were strongly agreed to supernatural elements and forced them for early marriages but $26 \%$ agree, $54 \%$ neutral, $4 \%$ disagree and $6 \%$ strongly disagree. An extended family system is one of the main cause of early marriages among other causes and the responses are as; $40 \%$ of professionals strongly agreed, $34 \%$ agree and $26 \%$ neutral. Moreover, print media of Gilgit-Baltistan did not highlight the suicide cases of girls due to early marriage, in this connection, $30 \%$ of the respondents strongly agreed while, $28 \%$ agree, $38 \%$ neutral while $4 \%$ disagree. In response to maternal mortality and domestic violence rate increases $66 \%$ of professionals strongly agreed, $14 \%$ agree, $10 \%$ neutral, $0 \%$ disagree and $10 \%$ strongly disagree.

- Seventy-two $(72 \%)$ of the professionals strongly agreed to early marriage practice and it is higher in rural areas than urban areas whereas $16 \%$ agree, $8 \%$ neutral, $0 \%$ disagree and $4 \%$ strongly disagree. Early marriages cause over population and poverty rises in the region, in this connection responses are as, $38 \%$ of the professionals strongly agreed, $40 \%$ agree, $12 \%$ neutral, $0 \%$ disagree and $10 \%$ strongly disagree. 


\section{Views of Professtionals Associated to Early Marriages}

Population n povertyincreased in GB
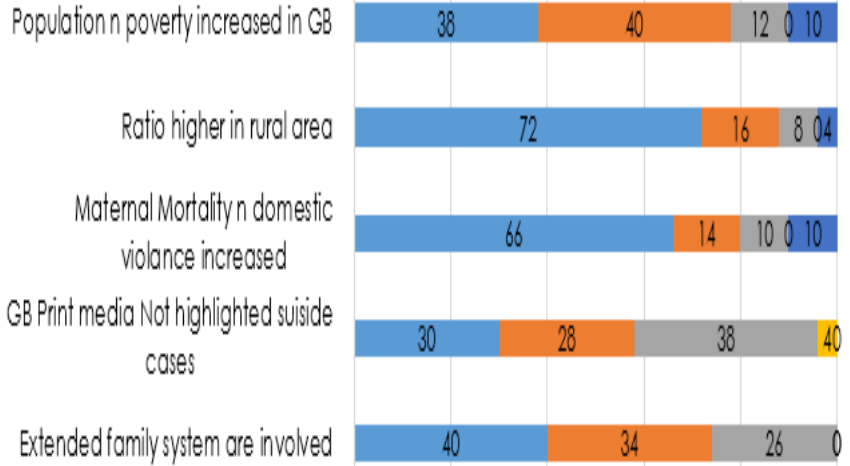

super natural forces is reason
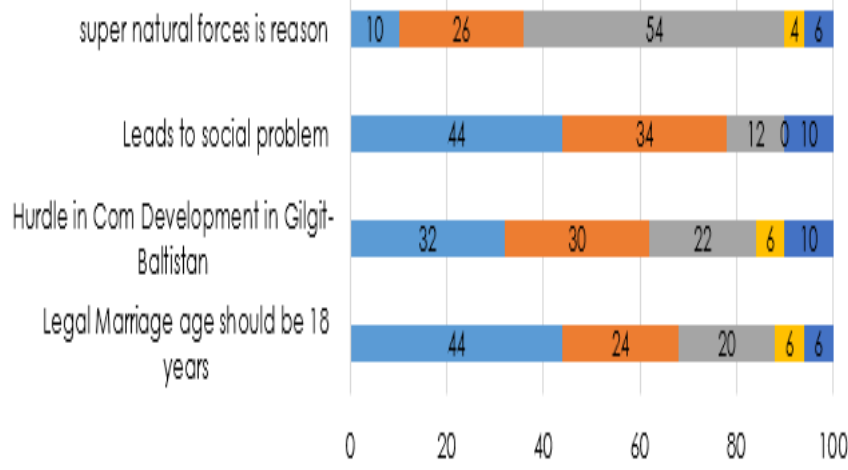

ustronlyogree $\|$ Agree $n$ Neutral $\|$ Disogree Instrongly disagree

We found $72 \%$ of the experts strongly agreed to early marriages and it is higher in rural areas than of urban settlement, similarly, according to Zia's study results were found as; $42 \%$ of early marriages and $24 \%$ of marriages occur in rural areas and $18 \%$ in urban areas. ${ }^{3}$ The same findings were found in Nasrullah and Zakar [23] study that stated from Pakistan Demographic and Health Survey showed $71 \%$ of early marriages were from rural while $30 \%$ in Urban areas [24].

We found $68 \%$ experts agreed to marriage age which is 18 years and they want to follow national and local marriage laws that are same and included in the CEDAW the issue of consent, a minimum age of marriage 18 years that outlaws discriminatory ages for both genders. While $80 \%$ of experts were agreed to directly involved in maternal morbidities and mortalities, however, $(n=109,72.6 \%)$ victims were not healthy because of early marriages. Although the same outcomes were shown in ending early marriage policy guide and in this report experts said that maternal morbidities and mortalities are major problems causes a high level of early marriages [22]. They have a double risk of dying during and after birth, furthermore, they increase chances of morbidities i.e. unbearable obstetric fistula. Over a quarter $78 \%$ of victims in the study could not continue their education because they have several family responsibilities and economic issues. It is also evident from earlier researches conducted in the country that describe $68 \%$ of victims were uneducated [23]. Although, found in the study of the role of low intake and birth weight was shown $72.5 \%$ women belongs to [up to 20 years] of age bracket that were low birth weight babies deliver [25] it is a strong association of early marriages is leading cause of low birth weight babies. The good nutrition is a requirement of the puberty age and due to early marriage which is insufficient for them and at the same time difficult to deliver nutrition to a newborn baby.

Legislation Assembly of Gilgit-Baltistan has blocked a bill seeking the ban on early marriage terming it Un-Islamic. Although, according to the survey conducted in all districts of Gilgit-Baltistan approx. 10,744 underaged from 15 to 49 years' women, $54 \%$ of the respondents got married before reaching 18 years. A difference of age between husband and wife is from 11 to 17 years whereas wives are younger and their husbands were in polygamous relationships [19].

\section{CONCLUSION}

The research paper shows that the experts such as legal practitioner, journalists, economist, psychologist, educationalist, civil society, human rights activists and physicians were well familiar to early marriages and its negative impacts on community development and victim's health outcomes. The victims are against an early marriage and its consequences for Society as well as their life i.e. their health, education, and their children live also effective due to this action. While the religious experts had an opinion that does not stop the early marriage which is un-Islamic and against the preaching of Islam and Sunnah. The dilemma of the research study is needed to take a serious step to eliminate the key indicators of early marriages. The victims married earlier were unaware about their marriage age and have been suffering from multiple issues in their life due to the burden of social and economic responsibilities. The Government, Civil Society, and NGOs might play a vital role to eradicate this social disease in Gilgit-Baltistan.

The issue of early marriage is ought to be raised in assemblies and various programs related to the issue are to be broadcasted for creating awareness 
in society towards early marriages. While there are laws that protect the innocent girls, there are considerable religious, cultural and social factors that overshadow these laws.

\section{Acknowledgment}

We would like to thanks all participants they gave us time, support to highlight the matter of Gilgit-Baltistan and in the accomplishment of the study. I acknowledged the efforts of Abrar Khan for assist in the collection of data in all district of Gilgit Baltistan.

\section{References}

[1] J. Svanemyr, V. Chandra-Mouli, A Raj, E Travers and L Sundaram, Research Priorities on ending child Marriage and Supporting married Girls. BMC Reproductive Health. 12 (80) (2015) 2-4.

[2] United Nation International Children's Emergency Funds. Ending Child Marriage: Progress and prospects. New York: (2014).

[3] Zia A. Underage married girls from Pakistan. Tribune. January 2, (2013).

[4] Abgeiki, "Coercion to Sex and Marriages in Ancient and Medieval Societies", Washington D.C., (1993) pg. 85-190.

[5] Retrieved from

http://www.icrw.org/files/images/Child-

Marriage-Fact-Sheet-By-The- Numbers.pdf

Accessed at 27th May 2017)

[6] S.M. Mathur, A. Greene, and Malthora. Too Young Too Wed The Lives, Rights, and Health of Young Married Girls. ICRW. (2003).

[7] A.S. Erulkar, T. Mekbib, N. Simie, and T. Gulema. "The experience of adolescence in rural Amhara region, Ethiopia." Accra: Population Council. (2004) 1-24.

[8] Kyari, Gimba Victor. And Ayodele, Joseph. "The Socio-Economic Effect of Early Marriage in North Western Nigeria", 5 $5^{\text {th }}$ (2014), pg. 58229.

[9] Retrieved from http://www.unicef.org/mdg/maternal.html Accessed on Aug 10 th, 2017.

[10] Clarks, Bracej, Dude, "Protecting Young Women", International Family Planning, Column 32: June (2016) 79:88

[11] Staff Reporter. Pakistan: WHO Report. The Daily Express. Ed., Dated on May 22nd, (2016). Karachi.

[12] UNICEF, "Young People and HIV/ Aids: Opportunity in Rises", A Joint report by UNICEF, UNAIDS, WHO. (2002).
[13] S. Asfaha, Independent Evolution Report. CAMFED and CAMA. Programs, Zimbabwe 1993-2003. (2003).

[14] M. Nasrullah, R. Zakar, A. Kramer: Effect of child marriage on use of maternal health care services in Pakistan. Obstet Gynecol 122: (2013) 517-524.

[15] Haider, Murtaza. Dated on Sep 7th, 2011. Retrieved from http://www.dawn.com/news/657239/bartered -in-marriage-the-bride- exchange-in-rural-pakistan Accessed at Sep 17th 2017.

[16] M. Nasrullah, R. Zakar, M.Z. Zakar, A. Kramer: Girl-child marriage and its association with morbidity and mortality of children under 5 years of age in a nationally-representative sample of Pakistan. I Pediatr, 164: (2014) 639-646.

[17] Unicef, Multiple Indicator Cluster Survey 2016-17: Gigit-Baltistan. The government of Gilgit-Baltistan (2017) 205-207.

[18] R. Abdul, J. Luan and H. Imran. The province-wide literacy rate in Pakistan and its impact on the conomy, Pacific science review B: Humanities and social sciences Vol 1(3) (2015) 140-144.

[19] S. Mir, "Underage, under law: G-B Lawmakers Blocks Bill to ban Child Marriages", The Express Tribune. Dec $9^{\text {th }},(2015)$.

[20] The Nation, Suicide incidents in Gilgit-Baltistan have reached an alarming level June 21, (2017) Retrieved from http://nation.com.pk/21-Jun-2017/suicideincidents-in-gb-have-reached-an-alarming-level accessed at Nov 15, 2017.

[21] A. Saif ur Rehman. Early Marriages in Pakistan", Chitral Pakistan, The Chitral Times. April $4^{\text {th }},(2014)$.

[22] UNFPA. Ending Child Marriage: AGuide for Global Policy action. London: International Planned Parenthood Federation. (2006): 1-32.

[23] M. Nasrullah, R. Zakar, M.Z. Zakar, S. Abbas, R. Safdar, M. Shaukat and A. Kramer. Knowledge and attitude towards child marriages practices among women married as children-a qualitative study in urban slums of Lahore, Pakistan. BMC Public Health, (2014), 14:1148

[24] National Institute of Population Studies (NIPS) [Pakistan] and Macro International Inc. Pakistan Demographic and Health Survey 2006-07. Islamabad, Pakistan: National Institute of Population Studies and Macro International Inc (2008).

[25] S. Baig, and F.H. Siddique, The Role of Prenatal Low Intake and Low Birth Weight among Deceased Infant. Journal of Social Sciences and Humanities, Vol (52)-2 (2013).83-96. 